\title{
Densely quaternized anion exchange membranes synthesized from Ullmann coupling extension of ionic segments for vanadium redox flow batteries
}

\author{
Yu Chen ${ }^{1}$, Qilang Lin ${ }^{1}$, Yuying Zheng ${ }^{1}$, Yan $\mathrm{Yu}^{1,2}$ and Dongyang Chen ${ }^{1,2^{*}}$
}

\begin{abstract}
Membranes with high ion conductivity and selectivity are important for vanadium redox flow batteries. Herein, densely quaternized anion exchange membranes based on quaternary ammonium functionalized octa-benzylmethyl-containing poly(fluorenyl ether ketone)s (QA-OMPFEKs) were prepared from the (i) condensation polymerization of a newly developed octa-benzylmethyl-containing bisphenol monomer via Ullmann coupling, (ii) bromination at the benzylmethyl sites using $\mathrm{N}$-bromosuccinimide, and (iii) quaternization of the bromomethyl groups using trimethylamine. The QA-OMPFEK-20 with an ion exchange capacity (IEC) of $1.66 \mathrm{mmol} \mathrm{g}^{-1}$ exhibited a higher $\mathrm{SO}_{4}{ }^{2-}$ conductivity $\left(9.62 \mathrm{mS} \mathrm{cm}^{-1}\right)$ than that of the QA-TMPFEK-40 $\left(4.82 \mathrm{mS} \mathrm{cm}^{-1}\right)$ at room temperature, which had a slightly higher IEC of $1.73 \mathrm{mmol} \mathrm{g}^{-1}$ but much lower QA density. The enhanced $\mathrm{SO}_{4}{ }^{2-}$ conductivity of QA-OMPFEK-20 was attributed to the ion-segregated structure arising from the densely anchored QA groups, which was validated by SAXS observation. Furthermore, the QA-OMPFEK-20 showed much lower $\mathrm{VO}^{2+}$ permeability $\left(1.24 \times 10^{-14} \mathrm{~m}^{2} \mathrm{~s}^{-1}\right)$ than QA-TMPFEK-40 $\left(5.40 \times 10^{-13} \mathrm{~m}^{2} \mathrm{~s}^{-1}\right)$ and Nafion N212 $\left(5.36 \times 10^{-12} \mathrm{~m}^{2} \mathrm{~s}^{-1}\right)$, leading to improved Coulombic and energy efficiencies in Vanadium redox flow batteries (VRFBs). Therefore, the Ullmann coupling extension is a valuable approach for the development of high performance anion exchange membranes for VRFBs.
\end{abstract}

Keywords: anion exchange membranes, quaternary ammonium, poly(fluorenyl ether ketone)s, Ullmann coupling extension, phase separation

\section{INTRODUCTION}

Vanadium redox flow batteries (VRFBs) are of tremendous interest over the past decades, owing to their outstanding merits such as low cost, fast response, high efficiency, good cycling stability, and promising application in large-scale energy storage [1-3]. As one of the key components in VRFBs, ion exchange membranes (IEMs) act as the separator sandwiching between catholyte and anolyte to prevent the cross-mixing of the electrolytes while allowing the migration of conductive ions $\left(\mathrm{H}^{+}\right.$or $\mathrm{SO}_{4}{ }^{2-}$ ) to complete the electrical circuit. An ideal IEM should possess high ion conductivity, low vanadium permeability, robust mechanical strength, and good chemical stability $[4,5]$. Nafion, a typical perfluorinated sulfonic acid membrane developed by DuPont, has been widely acknowledged as the benchmark material for VRFBs due to its high proton conductivity and excellent chemical stability. However, it has been limited by the high vanadium permeability and high cost [6,7]. Many efforts have been focused on modified Nafion [8] or alternative hydrocarbon IEMs such as sulfonated poly(arylene ether) [9] and pyridinium-functionalized poly $(2,6-$ dimethyl-1,4-phenyleneoxide), etc. [10]. Among them, the anion exchange membranes (AEMs) have attracted lots of attention because of their ultra-low vanadium permeability and high Coulombic efficiency rooted from the Donnan exclusion effect [11].

Quaternary ammonium (QA) functionalized poly (arylene ether)s (PAEs) are of a significant category of AEM materials that have been widely studied over the past decade [12-16]. Various backbone structures have been reported, including poly(2,6-dimethyl-1,4-phenylene oxide)s [17-20], poly(fluorenyl ether ketone)s [21], poly(fluorenyl ether sulfone)s [22,23], poly(phenolphthalein ether sulfone nitrile)s [24], poly(phthalazinone ether ketone)s, etc. [4]. These AEMs are usually flexible and robust, with tunable ion exchange capacities (IECs), water uptakes, and anion conductivities $[25,26]$.

${ }^{1}$ College of Materials Science and Engineering, Fuzhou University, Fuzhou 350116, China

${ }^{2}$ Key Laboratory of Eco-materials Advanced Technology (Fuzhou University), Fuzhou 350116, China

* Corresponding author (email: dongyang.chen@fzu.edu.cn) 
While their alkaline stability is limited for alkaline fuel cell/electrolyzer applications, their stability under acidic or neutral conditions is reasonably high, making them very attractive for those devices that are operating under non-alkaline conditions $[3,4]$.

It is still challenging to synthesize QA functionalized PAEs with enhanced anion conductivities for AEMs using new chemistries. Conventionally, QA functionalized PAEs are synthesized by either chloromethylation or bromomethylation of the PAE precursors and their subsequent reaction with a desired amine (most often trimethylamine). For chloromethylation route, the PAE precursors should contain electron-rich phenyl rings that are not connected to any electron-withdrawing group such as ketone or sulfone. Nevertheless, the chloromethylation requires the use of carcinogenic chloromethylation reactant (e.g., chloromethyl methyl ether), and the reaction degree is hard to control, with the risk of cross-linking [27]. These drawbacks hindered the employment of chloromethylation in the design and preparation of high performance AEMs. In contrast, the bromomethylation route uses benzylmethyl-containing PAE precursors and non-carcinogenic bromomethylation reactant (e.g., $\mathrm{N}$-bromosuccinimide). A reaction degree of $70 \%-80 \%$ can be easily achieved without the risk of crosslinking. Therefore, many studies have been focused on the synthesis of benzylmethyl-containing PAE precursors with special structures for bromomethylations $[28,29]$.

The most straightforward technique to achieve high anion conductivity in AEMs at a given IEC is to create phase segregated morphologies, where the ion-containing hydrophilic phase forms ionic channels for efficient anion conduction [30]. For the bromomethylation route, it is important to tether the benzylmethyl groups to a confined segment of polymer chains, so that the bromomethylation and quaternization can be directed to that confined segment for the formation of ion clusters. Note that the poly(2,6-dimethyl-1,4-phenylene oxide) (PPO) is a commercially abundant and relatively cheap resin containing two benzylmethyl groups at each repeat unit. It can only be randomly brominated. Alternatively, those PAE precursors that are polymerized from multi-benzylmethyl-containing monomers have been brominated successfully at the targeted positions to result in the formation of distinct phase separations [31]. Previously, we have reported the synthesis of a monomer containing six benzylmethyl groups and the corresponding AEMs [32]. Enhanced anion conductivities have been obtained, inspiring us to further increase the number of benzylmethyl groups in monomers. Herein, we report our effort to (i) synthesize a novel bisphenol monomer containing eight benzylmethyl groups using Ullmann coupling extension -the first application of the reaction in the synthesis of multi-benzylmethyl containing monomers, (ii) the polymerization, bromination, and quaternization of the novel monomer to yield QA functionalized PAEs, (iii) the detailed characterization of the products for the understanding and development of high performance AEMs for VRFBs.

\section{EXPERIMENTAL SECTION}

\section{Materials}

9,9'-Bis(3,5-dimethyl-4-hydroxyphenyl)fluorene (DMHPF) was synthesized according to a previously reported method [33]. 4,4'-Difluorobenzophenone was recrystallized from ethanol. Other chemicals were obtained from commercial sources and used as received.

\section{Synthesis of octa-benzylmethyl-containing compound a}

The reaction route was depicted in Scheme 1. To a $500 \mathrm{~mL}$ three necked round-bottom flask equipped with a magnetic stirrer were charged $25.00 \mathrm{~g}(61.5 \mathrm{mmol})$ of DMHPF, $33.84 \mathrm{~g} \quad(157.3 \mathrm{mmol})$ of 4-bromo-2,6-dimethylanisole, $34.04 \mathrm{~g}(246.5 \mathrm{mmol})$ of anhydrous po-

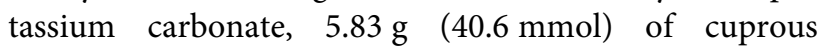
bromide, $21 \mathrm{~mL}$ of pyridine, and $300 \mathrm{~mL}$ of $N, N$-dimethylformamide. The mixture was refluxed under argon atmosphere at $165^{\circ} \mathrm{C}$ for a week. After cooling down, the black reaction mixture was carefully acidified with hydrochloric acid to a $\mathrm{pH}$ 2. A brown solid was precipitated from the reaction mixture, which was removed by filtration. The remaining mixture was diluted with $500 \mathrm{~mL}$ of deionized water and extracted with dichloromethane (DCM). The DCM phase was collected, dried over anhydrous $\mathrm{MgSO}_{4}$, filtrated, and evaporated, yielding $14.35 \mathrm{~g}$ of dark brown and viscous oil product. The product was purified by column chromatography using cyclohexane and DCM as eluents to achieve compound a as a white solid with $29.1 \%$ yield.

\section{Synthesis of octa-benzylmethyl-containing compound $\mathbf{b}$}

To a $250 \mathrm{~mL}$ three necked round-bottom flask were added $5.17 \mathrm{~g}(7.66 \mathrm{mmol})$ of compound a and $130 \mathrm{~mL}$ of DCM. $4.66 \mathrm{~g}(18.5 \mathrm{mmol})$ of boron tribromide was mixed with $18.5 \mathrm{~mL}$ of DCM, and added dropwise to the flask at about $-78^{\circ} \mathrm{C}$ under Ar atmosphere during a course of $\sim 1 \mathrm{~h}$. After that, the reaction temperature was allowed to increase to room temperature naturally. The reaction mixture was stirred at room temperature for $10 \mathrm{~h}$, diluted 

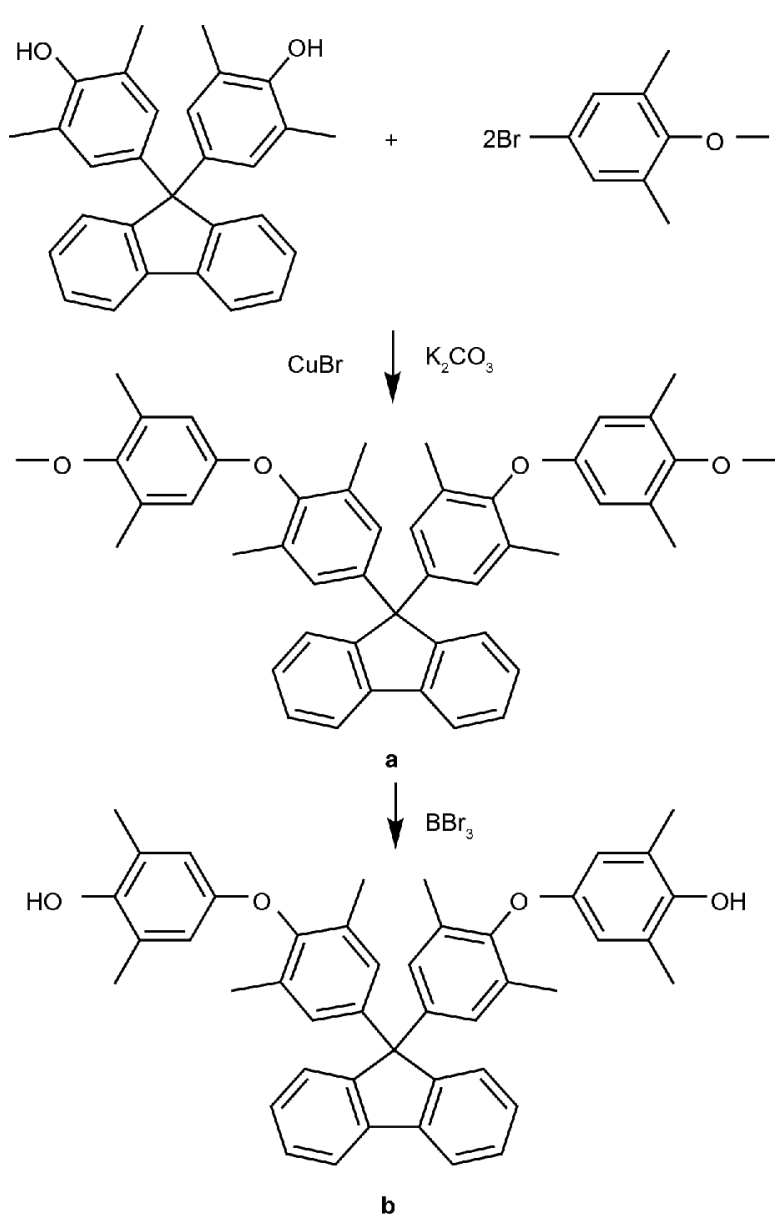

Scheme 1 Synthesis of octa-benzylmethyl-containing compounds a and b.

with $200 \mathrm{~mL}$ of DCM, extracted with deionized water, dried over anhydrous $\mathrm{MgSO}_{4}$, and then concentrated. The product was subjected to column chromatography using cyclohexane and DCM as eluents to give pure compound b in nearly quantitative yield.

\section{Copolymerization}

As depicted in Scheme 2, the octa-benzylmethyl-containing compound $\mathbf{b}$ was copolymerized with various amounts of 4,4'-difluorobenzophenone and 9,9-bis(4hydroxyphenyl)fluorene to yield octa-benzylmethyl-containing poly(fluorenyl ether ketone)s. The polymers were noted as OMPFEK- $x$, where $x$ represents the molar content of compound $\mathbf{b}$ in the bisphenol compounds. The representative synthesis of OMPFEK-20 was given as follows. To a $25 \mathrm{~mL}$ three necked round-bottom flask equipped with a Dean-Stark trap, an Ar inlet and outlet, a magnetic stirrer and a condenser were charged $0.3881 \mathrm{~g}$
(0.6 mmol) of compound $\mathbf{b}, 0.8410 \mathrm{~g}(2.4 \mathrm{mmol})$ of 9,9bis(4-hydroxyphenyl)fluorene, $0.6546 \mathrm{~g}$ (3 mmol) of 4,4'difluorobenzophenone, $0.6219 \mathrm{~g}(4.5 \mathrm{mmol})$ of $\mathrm{K}_{2} \mathrm{CO}_{3}$, $10 \mathrm{~mL}$ of $N, N$-dimethylacetamide (DMAc), and $6 \mathrm{~mL}$ of toluene. The mixture was heated at $\sim 145^{\circ} \mathrm{C}$ for $3 \mathrm{~h}$ under $\mathrm{Ar}$ atmosphere to remove the produced water, and then the toluene was distilled out of the mixture. After that, the reaction temperature was raised to $165^{\circ} \mathrm{C}$ and maintained for $15 \mathrm{~h}$. Lastly, the reaction temperature was cooled down to $\sim 80^{\circ} \mathrm{C}$, and the viscous mixture was poured into deionized water to form a fiberlike solid, which was collected by filtration, purified by re-dissolving in DCM and precipitating in methanol, and then dried under vacuum at $80^{\circ} \mathrm{C}$ for $24 \mathrm{~h}$.

\section{Bromination}

The OMPFEKs were brominated using one equivalent of $\mathrm{N}$-bromosuccinimide (NBS) per benzylmethyl group, as depicted in Scheme 2. A typical procedure for the synthesis of Br-OMPFEK-20 was shown as follows: $1.00 \mathrm{~g}$ of OMPFEK-20, $0.50 \mathrm{~g}(2.72 \mathrm{mmol})$ of NBS, $0.03 \mathrm{~g}$ $(0.14 \mathrm{mmol})$ of benzoyl peroxide and $20 \mathrm{~mL}$ of 1,2-dichloroethane were placed into a $50 \mathrm{~mL}$ three-necked flask. The mixture was heated at $85^{\circ} \mathrm{C}$ for $5 \mathrm{~h}$ under an argon atmosphere. Upon cooling to room temperature, the mixture was poured into $200 \mathrm{~mL}$ of methanol. Fibrous solid was formed and collected by filtration. The solid was re-dissolved in DCM, precipitated in methanol, collected by filtration, and dried under vacuum at $60^{\circ} \mathrm{C}$ for $24 \mathrm{~h}$. The products were named as Br-OMPFEK- $x$, where $x$ represents the molar content of compound $\mathbf{b}$ in the bisphenol compounds during polymerization.

\section{Quaternization}

As shown in Scheme 2, the Br-OMPFEK- $x$ was quaternized by mixing the polymer solution with an excess amount of trimethylamine to yield QA-OMPFEK- $x$, where $x$ represents the molar content of compound $\mathbf{b}$ in the bisphenol compounds during polymerization. A typical procedure was given as follows: $0.55 \mathrm{~g}$ of $\mathrm{Br}$-OMPFEK-20 was dissolved in $10 \mathrm{~mL}$ of DMAc in a glass vial. $0.6 \mathrm{~mL}$ of trimethylamine aqueous solution ( $30 \mathrm{wt} \%)$ was added dropwise over a course of $3 \mathrm{~min}$. Then, the container was sealed, and the mixture was stirred at room temperature for $24 \mathrm{~h}$. After that, the mixture was poured into a glass plate and kept in an oven at $80^{\circ} \mathrm{C}$ to evaporate the solvents. A brown solid product QA-OMPFEK-20 was obtained. The prefix "QA" was used in the sample names to designate quaternary ammonium functionalized samples. 

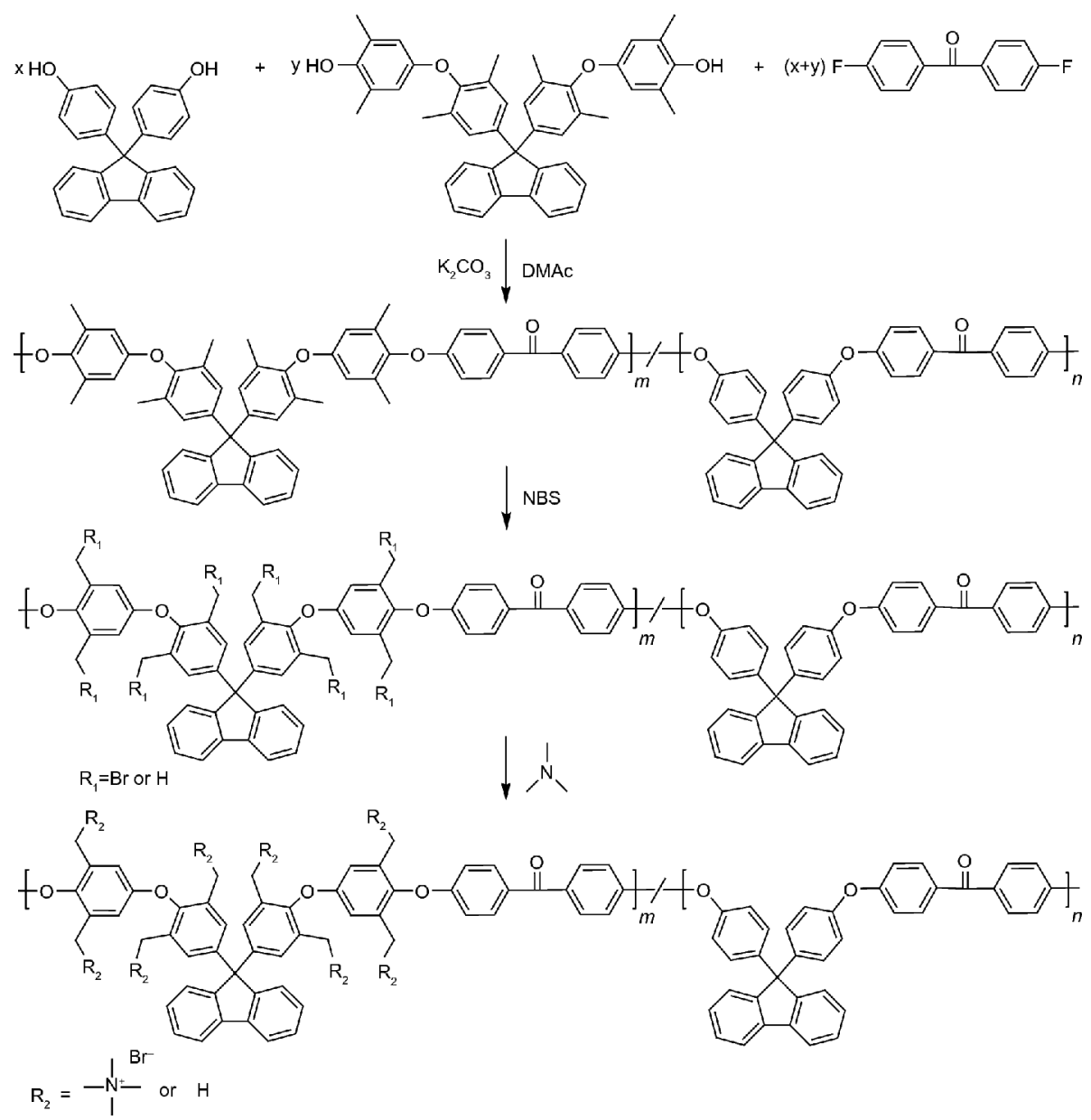

Scheme 2 Synthesis of OMPFEKs, Br-OMPFEKs, and QA-OMPFEKs.

\section{Membrane preparation}

The AEMs prepared by dissolving the QA-OMPFEKs in DMAc with a concentration of about $8 \mathrm{wt} / \mathrm{vol} \%$ and then filtered through a plug of cotton, cast onto a leveled glass plate, dried at $70^{\circ} \mathrm{C}$ under ambient pressure for $24 \mathrm{~h}$ and dried under vacuum at $80^{\circ} \mathrm{C}$ for an additional $24 \mathrm{~h}$. The membrane was peeled from the glass plate and stored in fresh deionized water. The $\mathrm{SO}_{4}{ }^{2-}$ form membranes were obtained by immersing the $\mathrm{Br}^{-}$form membranes in $1 \mathrm{~mol} \mathrm{~L}^{-1} \mathrm{Na}_{2} \mathrm{SO}_{4}$ for $24 \mathrm{~h}$, followed by immersing in deionized water for $24 \mathrm{~h}$ with water being refreshed three times.

\section{Characterization}

${ }^{1} \mathrm{H}$ NMR spectra were recorded on a Bruker AVANCE III 500 instrument and the chemical shifts were listed in parts per million (ppm) downfield from tetramethylsilane (TMS). FT-IR spectra were recorded on a Thermo Nicolet 5700 FT-IR spectrometer using the transmission mode.
Gel permeation chromatography (GPC) analysis was performed on a Malvern Viscotek system equipped with a Viscotek TDA305 detector. Tetrahydrofuran was used as the elution solvent with a flow rate of $1 \mathrm{~mL} \mathrm{~min}^{-1}$. Nearly monodisperse polystyrene standards were used for GPC calibration. The samples were fully dried prior to test. Small angle X-ray scattering (SAXS) data were collected on an Anton Paar SAXSess $\mathrm{mc}^{2}$ instrument. X-ray photoelectron spectroscopy (XPS) analysis was performed on a Thermo Scientific ESCALAB 250 spectrometer model with monochromatized $\mathrm{Al} \mathrm{Ka}$ radiation as the excitation source. Thermal stabilities were analyzed using a TA SDT-Q600 thermogravimetric analyzer (TGA) with a heating rate of $10^{\circ} \mathrm{C} \mathrm{min}{ }^{-1}$ under nitrogen atmosphere (flow rate: $100 \mathrm{~mL} \mathrm{~min}^{-1}$ ). Oxidative stability was evaluated under acidic conditions by immersing the membranes in $1 \mathrm{~mol} \mathrm{~L}^{-1} \mathrm{VO}_{2}^{+}+2 \mathrm{~mol} \mathrm{~L}^{-1} \mathrm{H}_{2} \mathrm{SO}_{4}$ solution at room temperature for two weeks and then recording weight loss of the sample and the color change of the 
solution. Mechanical properties were measured by a Suns universal testing instrument UTM 6502X. Rectangular samples $(100 \mathrm{~mm} \times 10 \mathrm{~mm})$ were taken out from deionized water and measured immediately with a stretching rate of $5 \mathrm{~mm} \mathrm{~min}^{-1}$. Inherent viscosity $(\eta)$ was measured at a concentration of $0.5 \mathrm{~g} \mathrm{dL}^{-1}$ using an Ubbelohde viscometer at room temperature.

IECs of QA-OMPFEKs were determined by titration. $0.2 \mathrm{~g}$ of membrane was immersed in $50 \mathrm{~mL}$ of $0.2 \mathrm{~mol} \mathrm{~L}^{-1}$ sodium nitrate aqueous solution for $24 \mathrm{~h}$. The amount of $\mathrm{Br}^{-}$released from the membrane was titrated with $0.1 \mathrm{~mol} \mathrm{~L}^{-1} \mathrm{AgNO}_{3}$ aqueous solution using potassium chromate as a colorimetric indicator. The IEC was calculated via the following equation: $\mathrm{IEC}=\Delta V_{\mathrm{AgNO} 3} C_{\mathrm{AgNO} 3} /$ $m_{\mathrm{d}}$, where $m_{\mathrm{d}}$ is the mass of the dry membrane, $\Delta V_{\mathrm{AgNO} 3}$ is the consumed volume of $\mathrm{AgNO}_{3}$ solution, and $\mathrm{C}_{\mathrm{AgNO}}$ is the concentration of $\mathrm{AgNO}_{3}$ solution.

Water uptake and swelling ratio of membranes were measured at $25,40,60$ and $80^{\circ} \mathrm{C}$. The samples were immersed in deionized water and equilibrated at the corresponding testing temperatures for $24 \mathrm{~h}$. The water uptake and swelling ratio were then calculated from the following equations: $W(\%)=\left(m_{\mathrm{w}}-m_{\mathrm{d}}\right) / m_{\mathrm{d}} \times 100 \% ; S(\%)=\left(l_{\mathrm{w}}\right.$ $\left.-l_{\mathrm{d}}\right) / l_{\mathrm{d}} \times 100 \%$, where $m_{\mathrm{d}}$ and $m_{\mathrm{w}}$ are the weight of the membranes before and after water absorption, respectively; $l_{\mathrm{w}}$ and $l_{\mathrm{d}}$ are the length of the membranes before and after water absorption, respectively.

In-plane ion conductivities of the membranes were measured by a Solartron 1260A frequency response analyzer as previously reported $[34,35]$. The samples were submerged in ultrapure water during measurements. The conductivities were calculated from the following equation: $\sigma=d / R A$; where the resistance $R$ is derived from the intercept of the low-frequency impedance with the $\operatorname{Re}\left(Z^{\prime}\right)$ axis, $S$ is the cross-sectional area available for ion transport, and $d$ is the distance between the two electrodes.

$\mathrm{VO}^{2+}$ permeability was measured according to the literature [36]. $35 \mathrm{~mL}$ of $1 \mathrm{~mol} \mathrm{~L}^{-1} \mathrm{VOSO}_{4}$ in $2 \mathrm{~mol} \mathrm{~L}^{-1}$ $\mathrm{H}_{2} \mathrm{SO}_{4}$ solution and $35 \mathrm{~mL}$ of $1 \mathrm{~mol} \mathrm{~L}^{-1} \mathrm{MgSO}_{4}$ in $2 \mathrm{~mol} \mathrm{~L}^{-1} \mathrm{H}_{2} \mathrm{SO}_{4}$ solutions were filled into two reservoirs separated by the membrane. $\mathrm{MgSO}_{4}$ was used to equalize the osmotic pressure between two reservoirs. The two solutions were continuously stirred at room temperature and the samples of the $\mathrm{MgSO}_{4}$ solution were taken at a regular time intervals for the measurement of $\mathrm{VO}^{2+}$ concentration using a Metash UV-5800HPC UV-vis spectrophotometer. The $\mathrm{VO}^{2+}$ permeability $(D)$ was calculated from: $V_{\mathrm{B}} \frac{\mathrm{d} C_{\mathrm{B}}(t)}{\mathrm{d} t}=A \frac{D}{L}\left(C_{\mathrm{A}}-C_{\mathrm{B}}(t)\right)$, where $C_{\mathrm{B}}$ is the concentration of permeated $\mathrm{VO}^{2+}$ ions in the $\mathrm{MgSO}_{4}$ compartment, $V_{\mathrm{B}}$ is the volume of $\mathrm{MgSO}_{4}$ solution $(35 \mathrm{~mL}), t$ is time for permeation, $A$ is membrane area exposed to electrolytes, $L$ is membrane thickness, and $C_{\mathrm{A}}$ is the initial concentration of $\mathrm{VOSO}_{4}\left(1 \mathrm{~mol} \mathrm{~L}^{-1}\right)$.

VRFBs were assembled according to a previous report $[37,38]$. The positive electrolyte was $100 \mathrm{~mL}$ of $1 \mathrm{~mol} \mathrm{~L}^{-1}$ $\mathrm{VO}^{2+}$ in $2 \mathrm{~mol} \mathrm{~L}^{-1} \mathrm{H}_{2} \mathrm{SO}_{4}$ solution, while the negative electrolyte was $50 \mathrm{~mL}$ of $1 \mathrm{~mol} \mathrm{~L}^{-1} \mathrm{VO}^{2+}$ in $2 \mathrm{~mol} \mathrm{~L}^{-1}$ $\mathrm{H}_{2} \mathrm{SO}_{4}$ solution. The batteries were tested at room temperature within a voltage window of $0.7-1.7 \mathrm{~V}$. The active area of the membrane was $15 \mathrm{~cm}^{2}$. The Coulombic efficiency (CE), voltage efficiency (VE) and energy efficiency (EE), were calculated by the following equations: $\mathrm{CE}=$ $\int I_{\mathrm{d}} \mathrm{d} t / \int I_{\mathrm{c}} \mathrm{d} t \times 100 \% ; \quad \mathrm{EE}=\int V_{\mathrm{d}} I_{\mathrm{d}} \mathrm{d} t / \int V_{\mathrm{c}} I_{\mathrm{c}} \mathrm{d} t \times 100 \% ; \quad \mathrm{VE}=\mathrm{EE} / \mathrm{CE}$ $\times 100 \%$ where $I_{\mathrm{d}}$ is the discharge current, $I_{\mathrm{c}}$ is the charge current, $V_{\mathrm{d}}$ is the discharge voltage, $V_{\mathrm{c}}$ is the charge voltage, and $t$ is the charge/discharge time.

\section{RESULTS AND DISCUSSION}

\section{Monomer synthesis}

The octa-benzylmethyl-containing compound $\mathbf{b}$ was synthesized by the Ullmann coupling of 9,9'-bis(3,5-dimethyl-4-hydroxyphenyl)fluorene (DMHPF) with 4-bromo-2,6-dimethyl anisole to yield an intermediate compound $\mathbf{a}$, which was then followed by $\mathrm{BBr}_{3}$ facilitated $\mathrm{O}$-demethylation. The chemical structures of compounds $\mathbf{a}$ and $\mathbf{b}$ were confirmed by ${ }^{1} \mathrm{H}$ NMR spectra, Fig. 1. For compound a, the singlet peaks at 2.05 and $2.23 \mathrm{ppm}$ are assigned to the two types of benzylmethyl groups (protons 1 and 2), and the singlet peak at $3.69 \mathrm{ppm}$ is assigned to the methoxyl groups (proton 3). For compound $\mathbf{b}$, the singlet peaks representing the benzylmethyl groups changes slightly to 2.03 and $2.19 \mathrm{ppm}$, and the singlet peak representing the methoxyl groups disappears. A new singlet peak at $4.32 \mathrm{ppm}$ is observed, which is assigned to the phenol groups (proton 3 ) of compound $\mathbf{b}$. These ${ }^{1} \mathrm{H}$ NMR results prove the successful extension of the tetrabenylmethyl-containing compound DMHPF to the octabenzylmethyl-containing compound $\mathbf{b}$. It is thus expected that such Ullmann coupling reaction can be applied to any other benzylmethyl-containing bisphenol monomers for AEMs.

\section{Polymer synthesis}

The octa-benzylmethyl-containing poly(fluorenyl ether ketone)s (OMPFEKs) were synthesized by the condensation polymerization of compound $\mathbf{b}$ with various amounts of 9,9-bis(4-hydroxyphenyl)fluorene and 4,4'difluorobenzophenone. Fibrous products with inherent 


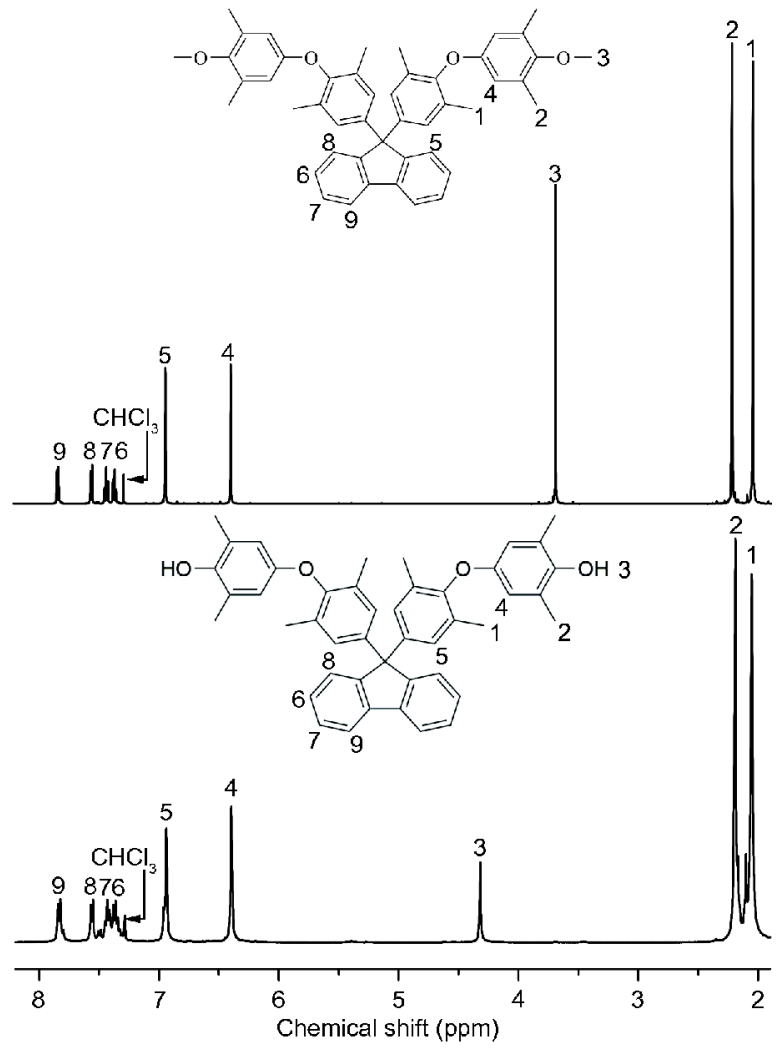

Figure $1{ }^{1} \mathrm{H}$ NMR spectra of octa-benzylmethyl-containing compounds $\mathbf{a}$ and $\mathbf{b}$ in $\mathrm{CDCl}_{3}$.

viscosity of $\sim 0.6 \mathrm{dL} \mathrm{g}^{-1}$ and number-average molecular weight of $\sim 60 \mathrm{kDa}$ were achieved (Table 1). The representative ${ }^{1} \mathrm{H}$ NMR spectra of OMPFEK-20 are shown in Fig. 2, with the two singlet peaks at 2.07 and $2.10 \mathrm{ppm}$ being assigned to the benzylmethyl groups. The bromination of OMPFEKs converted the benzylmethyl groups to the bromomethyl groups to yield Br-OMPFEKs, with the corresponding ${ }^{1} \mathrm{H}$ NMR peaks showing at 4.30 and $4.33 \mathrm{ppm}$. Based on the integral area ratio of the peak for the bromomethyl groups and the peak for the remaining benzylmethyl groups, a conversion degree of $\sim 80 \%$ can be derived for the Br-OMPFEKs. The number-average molecular weight of $\mathrm{Br}$-OMPFEKs are decreased to $\sim 50 \mathrm{kDa}$,
Table 1, probably because of minor cleavage of polymer backbone during bromination. Treating the Br-OMPFEKs with trimethylamine, the quaternary ammonium functionalized poly(fluorenyl ether ketone)s (QA-OMPFEKs) were obtained, as evidenced by the ${ }^{1} \mathrm{H} N M R$ spectrum in Fig. 2. It can be seen that a new broad peak at $\sim 3.23 \mathrm{ppm}$ shows up for the QA-OMPFEK-20 compared to the ${ }^{1} \mathrm{H}$ NMR spectrum of Br-OMPFEK-20. This broad peak indicates the successful conversion of bromomethyl groups to QA groups. In another word, the QA groups have been tethered successfully to the benzylmethylcontaining segments of OMPFEKs as designed.

The FT-IR spectra of the polymers were measured to give more structural information, Fig. 3a. The absorption peak at $3,063 \mathrm{~cm}^{-1}$ can be assigned to the vibration of aromatic $\mathrm{C}-\mathrm{H}$ bond. The absorption peaks at 2,951 and $2,916 \mathrm{~cm}^{-1}$ can be ascribed to the vibration of aliphatic $\mathrm{C}-\mathrm{H}$ bond on the methyl and/or methylene groups. The absorption peaks at 1,592 and $1,502 \mathrm{~cm}^{-1}$ can be assigned to the vibration of aromatic $\mathrm{C}=\mathrm{C}$ bond on the benzene rings. The absorption peak at $1,657 \mathrm{~cm}^{-1}$ can be assigned to the vibration of $\mathrm{C}=\mathrm{O}$ bond on the ketone groups. It should be noted that the FT-IR spectra for OMPFEK-20, Br-OMPFEK-20, and QA-OMPFEK-20 are nearly identical. This may be due to the low absorption intensity and the peak overlap of the new $\mathrm{C}-\mathrm{Br}$ and $\mathrm{C}-\mathrm{N}$ bonds with other functionalities on the OMPFEK backbones [32,39].

To further prove the composition of QA-OMPFEKs, the XPS survey spectrum were employed, Fig. $3 \mathrm{~b}$. The peaks at 284.6 and $532.3 \mathrm{eV}$ are observed for the emissions of $\mathrm{C} 1 \mathrm{~s}$ and $\mathrm{O} 1 \mathrm{~s}$ from the OMPFEK backbones, respectively. Moreover, a peak at $400.2 \mathrm{eV}$ is observed, which can be ascribed to the emission of $\mathrm{N} 1 \mathrm{~s}$. The existence of this peak clearly indicates the content of QA groups in the sample, a conclusion that cannot be drawn solely from the FT-IR results. The peaks at $68.3,181.4$ and $256.2 \mathrm{eV}$ can be ascribed to $\mathrm{Br} 3 \mathrm{~d}, 3 \mathrm{p}$ and $3 \mathrm{~s}$ emissions, indicating the existence of $\mathrm{Br}^{-}$as the counter anions. The XPS and FT-IR results are in good agreement with the ${ }^{1} \mathrm{H}$ NMR result, verifying the successful synthesis of QA-OMPFEKs.

Table 1 Inherent viscosities and molecular weights of the polymers

\begin{tabular}{cccccccccc}
\hline Sample & $\eta\left(\mathrm{dL} \mathrm{g}^{-1}\right)$ & $M_{\mathrm{n}}(\mathrm{kDa})$ & $M_{\mathrm{w}}(\mathrm{kDa})$ & PDI & $\eta^{\mathrm{a}}\left(\mathrm{dL} \mathrm{g}^{-1}\right)$ & $M_{\mathrm{n}}{ }^{\mathrm{a}}(\mathrm{kDa})$ & $M_{\mathrm{w}}{ }^{\mathrm{a}}\left(\mathrm{kDa}^{2}\right)$ & $\mathrm{PDI}^{\mathrm{a}}$ & $\eta^{\mathrm{b}}\left(\mathrm{dL} \mathrm{g}^{-1}\right)$ \\
\hline OMPFEK-10 & 0.66 & 64.4 & 186.8 & 2.9 & 0.47 & 51.4 & 133.6 & 2.6 & 1.09 \\
OMPFEK-15 & 0.57 & 62.4 & 174.7 & 2.8 & 0.53 & 55.1 & 177.6 & 3.2 & 1.14 \\
OMPFEK-20 & 0.65 & 64.9 & 194.7 & 3.0 & 0.52 & 53.0 & 153.7 & 2.9 & 1.26 \\
OMPFEK-25 & 0.69 & 65.8 & 204.0 & 3.1 & 0.55 & 54.9 & 148.2 & 2.7 & 1.33 \\
\hline
\end{tabular}

a) After bromination; b) after quaternization. 

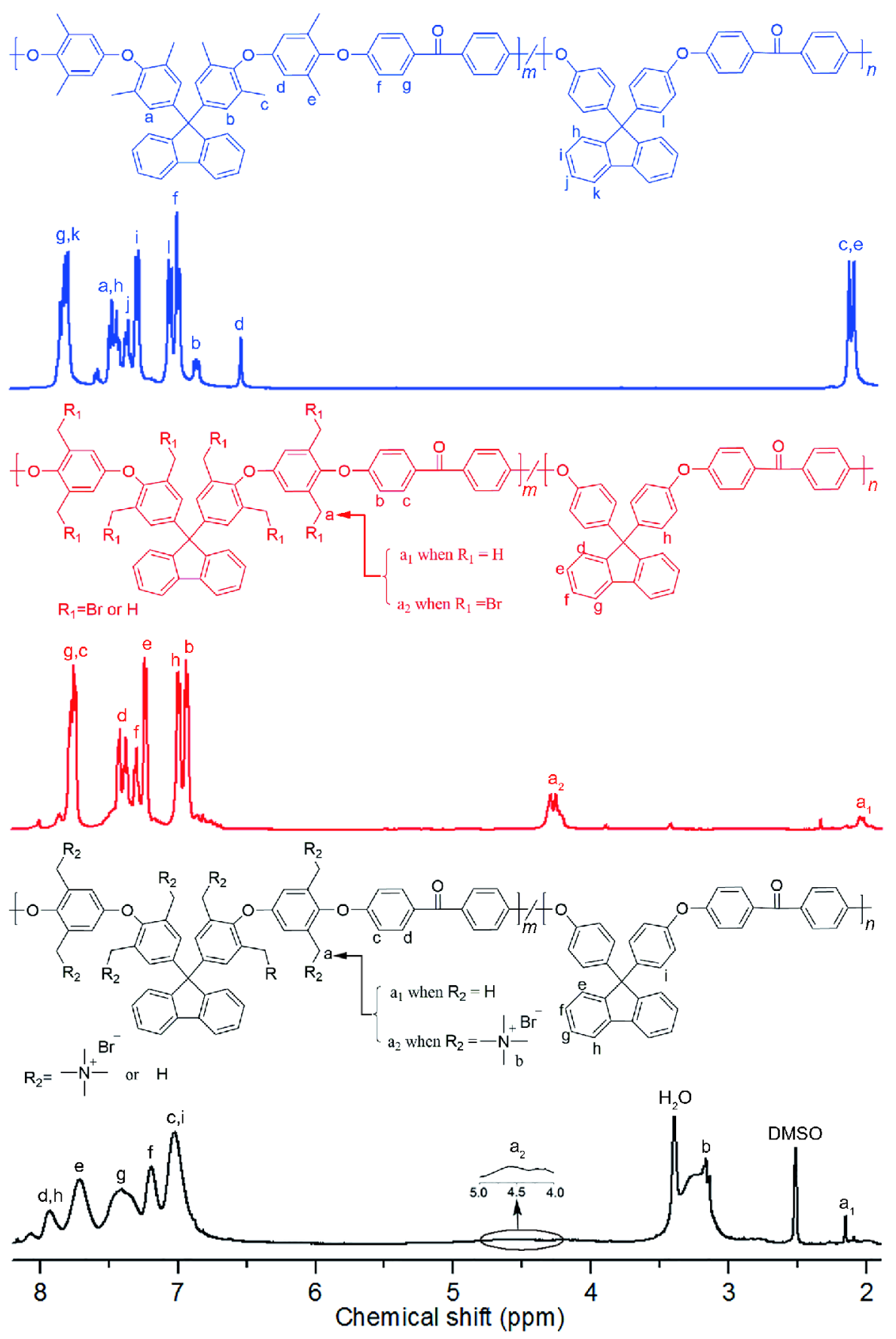

Figure $2{ }^{1} \mathrm{H}$ NMR spectra of OMPFEK-20 (in $\mathrm{CDCl}_{3}$ ), Br-OMPFEK-20 (in $\mathrm{CDCl}_{3}$ ), and QA-OMPFEK-20 (in DMSO- $\mathrm{d}_{6}$ ).

Water uptake, swelling ratio and anion conductivity Anion conductivity is a core property of AEMs, which is mainly affected by IEC, ion distribution, and water uptake [40]. In order to investigate the relationship among them, the water uptake, swelling ratio and anion conductivity of QA-OMPFEKs with different IECs and counter-ions were measured. A control AEM (QATMPFEK-40, Scheme 3) made from tetra-benzylmethylcontaining poly(fluorenyl ether ketone) was also characterized for comparison. The synthesis procedure for QA-TMPFEK-40 was documented in the Supplementary Information. Note that the benzylmethyl group content 

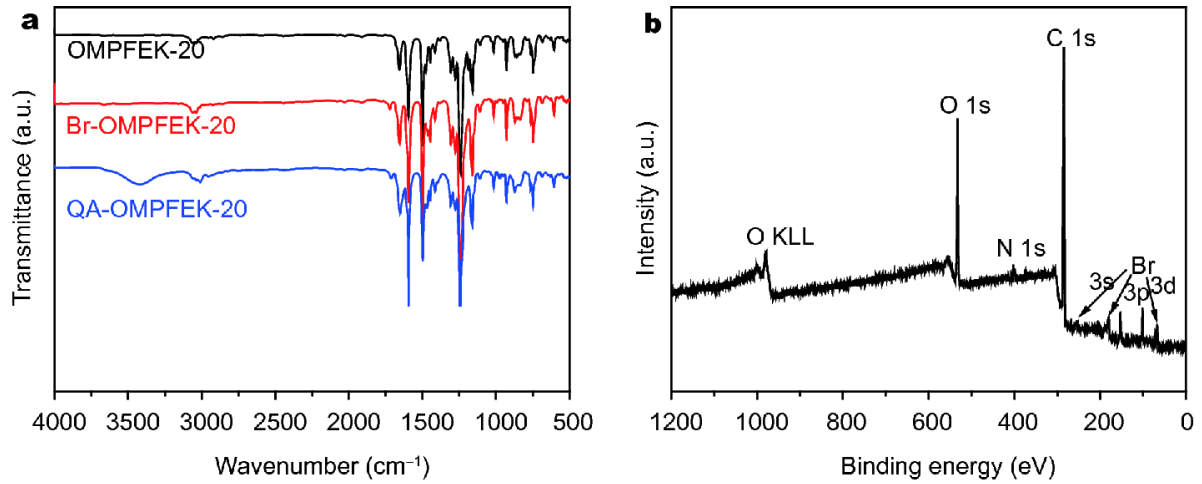

Figure 3 (a) FT-IR spectra of OMPFEK-20, Br-OMPFEK-20, and QA-OMPFEK-20; (b) XPS survey spectrum of QA-OMPFEK-20.

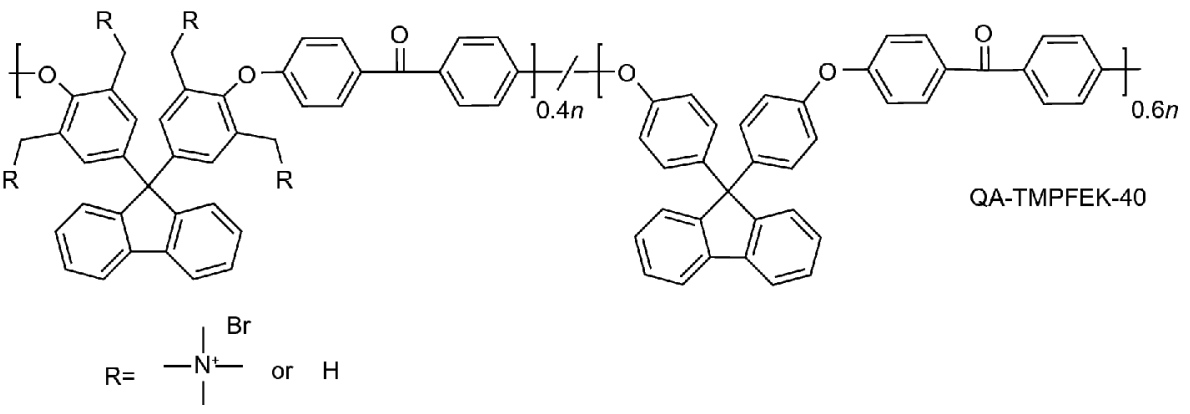

Scheme 3 The chemical structure of control sample QA-TMPFEK-40.

in TMPFEK-40 and OMPFEK-20 is almost the same, but the benzylmethyl group distribution is significantly different. Therefore, the performance difference of QA-TMPFEK-40 and QA-OMPFEK-20 would mainly arise from the distribution difference of the QA groups along the polymer backbone.

By varying the loading amount of octa-benzylmethylcontaining mononer $\mathbf{b}$, four QA-OMPFEKs with IECs ranging from 0.96 to $2.05 \mathrm{mmol} \mathrm{g}^{-1}$ were obtained, as shown in Table 2. At room temperature, the water uptake and swelling ratio of QA-OMPFEKs increase monotonically with the increasing IEC. For example, the water uptake of QA-OMPFEK-10 with the counter-ion of $\mathrm{Br}^{-}$is $9.9 \%$, while that of QA-OMPFEK-25 is $18.2 \%$. The $\mathrm{Br}^{-}$ conductivity of QA-OMPFEKs also increases with the increasing IEC, from $1.24 \mathrm{mS} \mathrm{cm}^{-1}$ of QA-OMPFEK-10 to $4.18 \mathrm{mS} \mathrm{cm}^{-1}$ of QA-OMPFEK-25. This increase in $\mathrm{Br}^{-}$ conductivity can be mainly attributed to the higher ionic content and higher degree of hydrophilicity of the QA-OMPFEKs with higher IECs. Since sulfate is the main charge carrier of the AEM in the VRFBs with sulfuric acid-based electrolyte [3], the water uptake, swelling ratio and conductivity of the $\mathrm{SO}_{4}{ }^{2-}$ form AEMs were also characterized and listed in Table 2. The $\mathrm{SO}_{4}^{2-}$ conductivity is found to be higher than the $\mathrm{Br}^{-}$conductivity, which may be attributed to the higher mobility of $\mathrm{SO}_{4}^{2-}$ and higher water uptake of samples in $\mathrm{SO}_{4}{ }^{2-}$ form compared to $\mathrm{Br}^{-}$form [41]. Weiber et al. [42] reported a series of polysulfone based AEMs with highly localized cation groups. The QA sample c4PAES-1.8Q had an IEC of $1.8 \mathrm{mmol} \mathrm{g}^{-1}$, a water uptake of $28 \%$, and a $\mathrm{Br}^{-}$conductivity of $1.3 \mathrm{mS} \mathrm{cm}^{-1}$ at $20^{\circ} \mathrm{C}$. Yun et al. [43] reported a QA functionalized poly(aryl ether ketone)s with an IEC of $1.54 \mathrm{mmol} \mathrm{g}^{-1}$ which showed a water uptake of $36 \%$ and a $\mathrm{SO}_{4}{ }^{2-}$ conductivity of $5.6 \mathrm{mS} \mathrm{cm}^{-1}$ at $30^{\circ} \mathrm{C}$. Therefore, the anion conductivity of QA-OMPFEK-20 is comparable to these similar systems with densely localized ionic groups.

It has been found that the QA-TMPFEK-40 has slightly higher IEC and water uptake than QA-OMPFEK-20, Table 2. Interestingly, the $\mathrm{Br}^{-}$and $\mathrm{SO}_{4}^{2-}$ conductivity of QA-TMPFEK- 40 is only $56.2 \%$ and $50.1 \%$ of those of QA-OMPFEK-20 at room temperature, respectively. To get a better understanding of this phenomenon, the water 
Table 2 Basic properties of QA-OMPFEKs and QA-TMPFEK-40 at room temperature

\begin{tabular}{|c|c|c|c|c|c|c|c|c|}
\hline \multirow{2}{*}{ Sample } & \multirow{2}{*}{$\begin{array}{c}\text { Targeted IEC } \\
\left(\mathrm{mmol} \mathrm{g}^{-1}\right)\end{array}$} & \multirow{2}{*}{$\begin{array}{l}\text { Titrated IEC } \\
\left(\mathrm{mmol} \mathrm{g}^{-1}\right)\end{array}$} & \multicolumn{2}{|c|}{ Water uptake (\%) } & \multicolumn{2}{|c|}{ Swelling ratio (\%) } & \multicolumn{2}{|c|}{$\sigma_{20^{\circ} \mathrm{C}}\left(\mathrm{mS} \mathrm{cm}^{-1}\right)$} \\
\hline & & & $\mathrm{a}$ & $\mathrm{b}$ & $\mathrm{a}$ & $\mathrm{b}$ & $\mathrm{a}$ & $\mathrm{b}$ \\
\hline QA-OMPFEK-10 & 1.20 & 0.96 & 9.9 & 19.1 & 3.6 & 6.5 & 1.24 & 3.34 \\
\hline QA-OMPFEK-15 & 1.62 & 1.31 & 12.4 & 25.1 & 4.3 & 9.2 & 1.89 & 5.70 \\
\hline QA-OMPFEK-20 & 1.98 & 1.66 & 14.9 & 33.3 & 5.0 & 12.1 & 2.74 & 9.62 \\
\hline QA-OMPFEK-25 & 2.27 & 2.05 & 18.2 & 42.9 & 6.0 & 14.6 & 4.18 & 14.36 \\
\hline QA-TMPFEK-40 & 2.07 & 1.73 & 18.0 & 38.8 & 6.6 & 13.2 & 1.54 & 4.82 \\
\hline
\end{tabular}

a) Samples with the counter-ion of $\mathrm{Br}^{-}$; b) samples with the counter-ion of $\mathrm{SO}_{4}{ }^{2-}$.

uptake, swelling ratio, and $\mathrm{SO}_{4}{ }^{2-}$ conductivity of QA-TMPFEK-40 and QA-OMPFEK-20 were also measured at higher temperatures $\left(40^{\circ} \mathrm{C}, 60^{\circ} \mathrm{C}\right.$ and $\left.80^{\circ} \mathrm{C}\right)$, and the results were plotted in Fig. 4. It can be seen that the QA-TMPFEK-40 has slightly higher water uptake and swelling ratio than QA-OMPFEK-20 under all the temperatures tested. However, the QA-OMPFEK-20 exhibited much higher $\mathrm{SO}_{4}^{2-}$ conductivity than QATMPFEK-40 under all the temperatures tested, Fig. 4c. The similar tendency can be seen in these samples with the counter ion of $\mathrm{Br}^{-}$, as shown in Figs S1 and S2 (Supplementary information). The $\mathrm{SO}_{4}{ }^{2-}$ conductivity of both the QA-OMPFEK-20 and QA-TMPFEK-40 follows an approximate Arrhenius-type temperature dependence, which is considered to be promoted by the thermal activation [44]. The apparent activation energies calculated from the plots are 19.0 and $17.8 \mathrm{~kJ} \mathrm{~mol}^{-1}$ for QA-OMPFEK-20 and QA-TMPFEK-40, respectively. Based on these observations, we surmise that the higher amount of QA groups on the specific segments (local charge density) of QA-OMPFEK-20 compared to QA-TMPFEK-40 may facilitate the formation of ionsegregated phase and lead to the increase in anion conductivity, despite the fact that the QA-OMPFEK-20 exhibits slightly lower water uptake and swelling ratio than

\section{QA-TMPFEK-40.}

\section{Membrane morphology}

The local density of quaternary ammonium groups in QA-OMPFEK-20 is nearly twice as that in QA-TMPFEK40, as depicted in Fig. 5a. To probe the phase behavior of QA-OMPFEK-20 and QA-TMPFEK-40, small-angle Xray scattering (SAXS) was employed, as shown in Fig. 5b. It can be seen that the SAXS pattern of QA-OMPFEK-20 exhibits an obvious scattering peak at $q=0.65 \mathrm{~nm}^{-1}$. Inter-domain distance $(d)$ is then calculated to be $9.2 \mathrm{~nm}$. In contrast, the SAXS pattern of QA-TMPFEK-40 doesn't exhibit any scattering peak above the baseline. Since the scattering peak for AEMs is originated from the ionsegregated phase [45], this SAXS result validates the existence of distinct phase separation in QA-OMPFEK-20 rather than QA-TMPFEK-40.

\section{Thermal stability}

The thermal properties of QA-OMPFEK-20 and QA-TMPFEK-40 were evaluated by thermogravimetric analysis (TGA) under $\mathrm{N}_{2}$ atmosphere. As shown in Fig. $6 \mathrm{a}$, the OMPFEK-20 and TMPFEK-40 are thermally stable up to $\sim 400^{\circ} \mathrm{C}$, a typical stability of poly(arylene ether) backbones [46]. After bromination, a two-stage
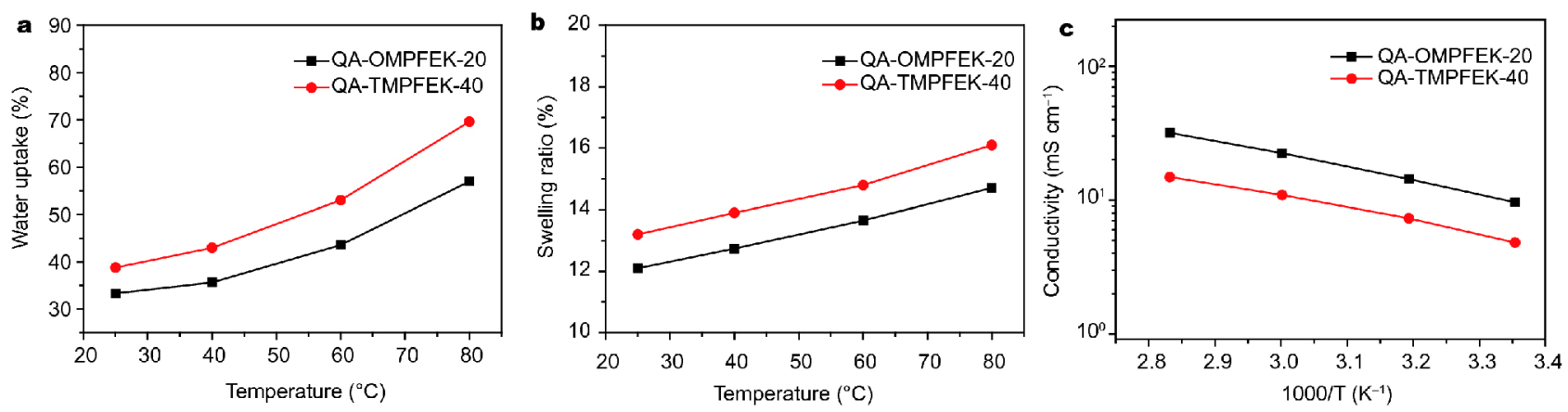

Figure 4 (a) Water uptake, (b) swelling ratio, and (c) $\mathrm{SO}_{4}{ }^{2-}$ conductivity of QA-OMPFEK-20 and QA-TMPFEK-40 ( $\mathrm{SO}_{4}{ }^{2-}$ form) as a function of temperature. 
a

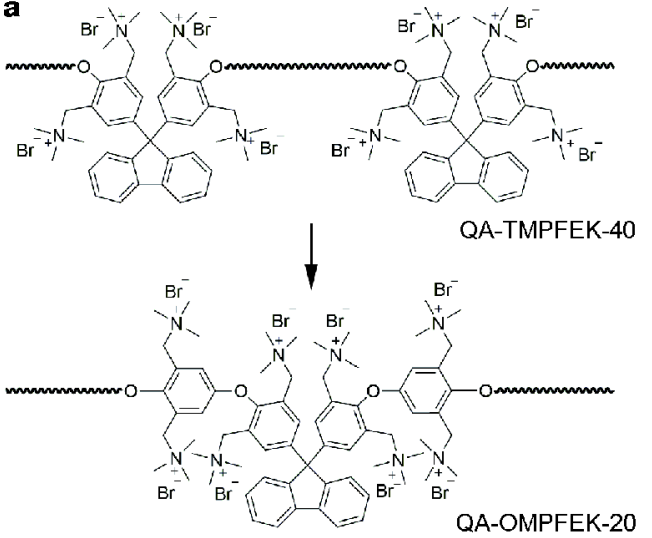

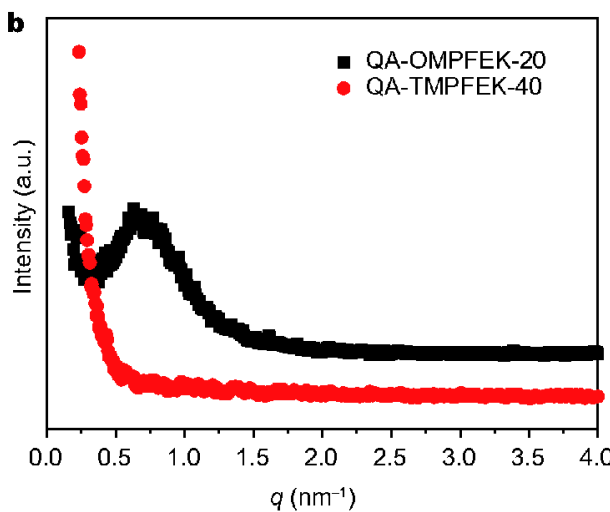

Figure 5 (a) Representative ion distributions in QA-OMPFEK-20 and QA-TMPFEK-40; (b) SAXS patterns of QA-OMPFEK-20 and QA-TMPFEK-40.

decomposition profile can be observed for both the samples, namely Br-OMPFEK-20 and Br-TMPFEK-40. The first stage can be attributed to the decomposition of the bromomethyl groups, while the second stage is still the decomposition of the aromatic backbones. The final quaternization step keeps lowering the initial decomposition temperature to $\sim 190^{\circ} \mathrm{C}$ while maintaining the two-stage decomposition profile of brominated samples. The first stage can be attributed to the decomposition of the QA groups, while the second stage is the decomposition of the aromatic backbones [21,27]. The 5\% weight-loss temperatures $\left(T_{\mathrm{d}-5 \%}\right)$ for QA-OMPFEK-20 and QA-TMPFEK- 40 are $236.0^{\circ} \mathrm{C}$ and $250.6^{\circ} \mathrm{C}$, respectively. Therefore, the thermal stability of both the QA-OMPFEK-20 and QA-TMPFEK-40 are satisfying for AEM applications.

\section{Mechanical property}

The mechanical properties of AEMs are critically important for the device fabrications. Usually, the mechanically weak membranes need to be thick enough and perhaps supported by other matrix, resulting in the high resistance of the membrane toward ion conduction. However, the mechanically strong membranes can be made into stand-alone and thin membranes with low resistance. The stress-strain curves of QA-OMPFEK-20, QA-TMPFEK-40, and Nafion N212 were shown in Fig. 6b. It can be seen that Nafion N212 has the lowest tensile strength while the highest elongation-at-break. The QAOMPFEK-20 is more robust than the QA-TMPFEK-40, with a tensile strength of $32.1 \mathrm{MPa}$ and an elongation-atbreak of $15.9 \%$ for the former comparing to a tensile strength of 24.4 MPa and an elongation-at-break of $14.6 \%$ for the latter. This is most likely because that the
QA-TMPFEK-40 has slightly higher water uptake than QA-OMPFEK-20 as shown above, and the water can act as plasticizer in the membrane to decrease the cohesion of the polymer chains. Nevertheless, the mechanical properties of both the QA-OMPFEK-20 and QA-TMPFEK-40 are promising as compared to other similar systems that have been demonstrated to be suitable for AEM applications $[32,47]$.

\section{Chemical stability}

The oxidative stability of QA-OMPFEK-20, QATMPFEK-40 and Nafion N212 under acidic conditions was studied by immersing the membranes in $1 \mathrm{~mol} \mathrm{~L}^{-1}$ $\mathrm{VO}_{2}^{+}+2 \mathrm{~mol} \mathrm{~L}^{-1} \mathrm{H}_{2} \mathrm{SO}_{4}$ solution at room temperature for two weeks. The digital photos of the solutions before and after the test were taken and shown in Fig. 7a, b. It can be seen that the color of the solutions after $14 \mathrm{~d}$ is almost unchanged. The samples remain intact and flexible after the immersion. The weight remaining for the QAOMPFEK-20, QA-TMPFEK-40 and Nafion N212 after the two-week immersion are $95.9 \% \pm 3.1 \%, 97.1 \% \pm 2.5 \%$, and $97.5 \% \pm 2.2 \%$, respectively, indicating that QA-OMPFEK-20 and QA-TMPFEK-40 are reasonably stable under this acidic and oxidative condition.

\section{VRFB performance}

The QA-OMPFEK-20 was evaluated against QATMPFFEK-40 and Nafion $\mathrm{N} 212$ as the separator for VRFBs. The $\mathrm{VO}^{2+}$ permeability of the membranes was measured according to a conventional method since it is one of the key parameters for VRFB separators $[30,48]$. It is found that the $\mathrm{VO}^{2+}$ permeability of QA-OMPFEK-20 $\left(1.24 \times 10^{-14} \mathrm{~m}^{2} \mathrm{~s}^{-1}\right)$ is lower than that of QA-TMPFEK-40 $\left(5.40 \times 10^{-13} \mathrm{~m}^{2} \mathrm{~s}^{-1}\right)$. This is probably because that the 

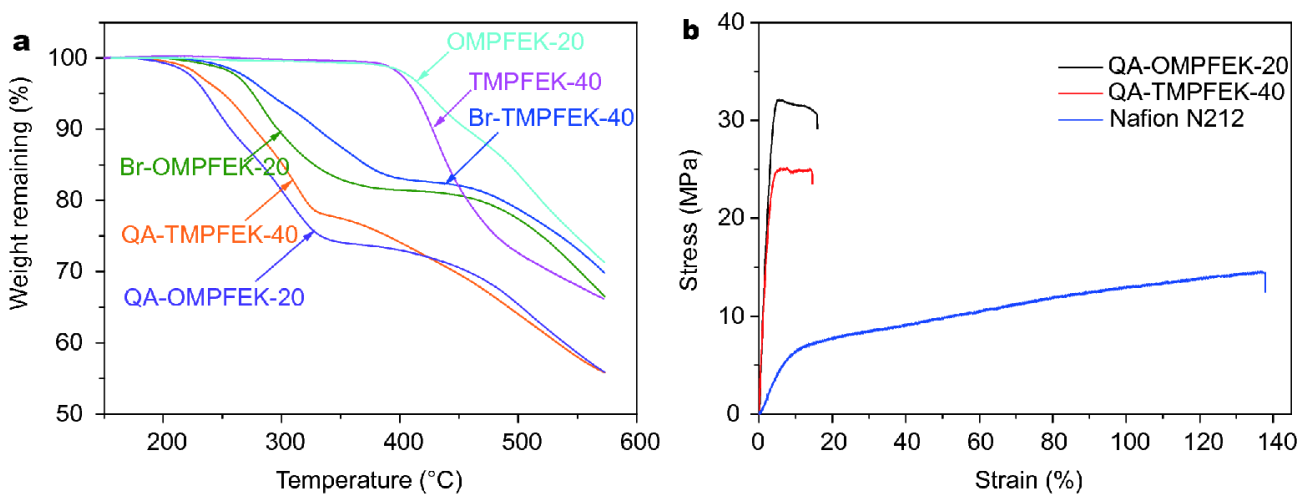

Figure 6 (a) TGA curves of PFEKs, Br-PFEKs, and QA-PFEKs; (b) stress-strain curves of QA-OMPFEK-20, QA-TMPFEK-40 and Nafion N212.

water uptake of QA-TMPFEK-40 is higher than that of QA-OMPFEK-20 as shown above, which enhances the permeation of $\mathrm{VO}^{2+}$. Interestingly, the $\mathrm{VO}^{2+}$ permeability of QA-OMPFEK-20 and QA-TMPFEK-40 are more than one magnitude's lower than that of Nafion N212 $\left(5.36 \times 10^{-12} \mathrm{~m}^{2} \mathrm{~s}^{-1}\right)$. This can be attributed to the Coulombic repulsion of the vanadium species by the QA groups of the AEMs $[3,38]$.

The charge/discharge performances of the QA-OMPFEK-20, QA-TMPFEK-40 and Nafion N212 batteries were measured at a current density of $40 \mathrm{~mA} \mathrm{~cm}$. As shown in Fig. 8a, the QA-OMPFEK-20 battery has longer charge/discharge time than the QA-TMPFEK-40 battery, presumably because of the lower $\mathrm{VO}^{2+}$ permeability of QA-OMPFEK-20. The Coulombic efficiency (CE) of the QA-OMPFEK-20 battery is thus calculated to be $94.0 \%$, higher than that of the QA-TMPFEK-40 battery (89.9\%). Moreover, the voltage efficiency (VE) of the QA-OMPFEK-20 battery $(86.8 \%)$ is also higher than that of the QA-TMPFEK-40 battery (85.5\%), which is most likely due to the higher $\mathrm{SO}_{4}^{2-}$ conductivity of QA-OMPFEK-20 as shown above. The Nafion N212 battery has the lowest Coulombic efficiency $(88.4 \%)$ while the highest voltage efficiency (87.9\%), which can be attributed to the highest $\mathrm{VO}^{2+}$ permeability and proton conductivity $\left(74.4 \mathrm{mS} \mathrm{cm}^{-1}\right)$ of Nafion. Nevertheless, the energy efficiency (EE) of the QA-OMPFEK-20 battery (81.6\%) is the highest among all the three batteries.

The cycling stability of the QA-OMPFEK-20, QA-TMPFEK-40 and Nafion N212 batteries at a current density of $40 \mathrm{~mA} \mathrm{~cm}^{-2}$ is shown in Fig. $8 \mathrm{~b}$. It can be seen that all of the three VRFBs show minor change in both $\mathrm{CE}$ and EE after 20 cycles, implying the remarkable stability of the batteries. The decay of discharge capacity of the three VRFBs during cycling is shown Fig. 8c. It can be seen that the QA-OMPFEK-20 battery exhibits the lowest
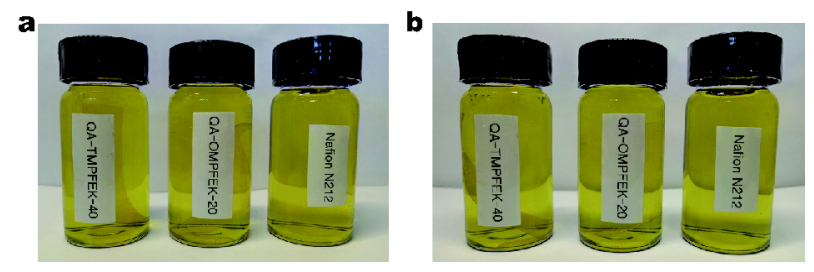

Figure 7 Digital photos of QA-OMPFEK-20, QA-TMPFEK-40 and Nafion N212 immersing in $1 \mathrm{~mol} \mathrm{~L}^{-1} \mathrm{VO}_{2}^{+}+2 \mathrm{~mol} \mathrm{~L}^{-1} \mathrm{H}_{2} \mathrm{SO}_{4}$ solutions (a) at $0 \mathrm{~d}$ and (b) after $14 \mathrm{~d}$.

capacity decay after 20 cycles. This could be attributed to the lowest $\mathrm{VO}^{2+}$ permeability of the QA-OMPFEK-20 among the three membranes.

The rate performance of the QA-OMPFEK-20, QA-TMPFEK-40 and Nafion N212 batteries is shown in Fig. 8d. It can be seen that the CE of the VRFBs increases with the increasing current density, which may be attributed to the less crossover of the vanadium ions at the higher current densities because of the shorter charge/ discharge time. The VE of the VRFBs decreases with the increasing current density, which can be attributed to the higher Ohmic polarization at higher current densities [5,49]. The maximum $\mathrm{EE}$ is found to be $79.8 \%, 78.7 \%$, and $82.0 \%$ for the Nafion N212, QA-TMPFEK-40, and QA-OMPFEK-20 batteries, respectively, at a current density of $60 \mathrm{~mA} \mathrm{~cm}^{-2}$. Given these promising cell performance, it can be concluded that the QA-OMPFEK-20 is a highly promising candidate for VRFBs.

\section{CONCLUSIONS}

An octa-benzylmethyl-containing bisphenol compound $\mathbf{b}$ was successfully synthesized from a tetra-benzylmethylcontaining bisphenol compound (DMHPF) by Ullmann coupling extension with 4-bromo-2,6-dimethylanisole followed by $\mathrm{BBr}_{3}$ facilitated O-demethylation. A series of QA functionalized octa-benzylmethyl-containing poly 

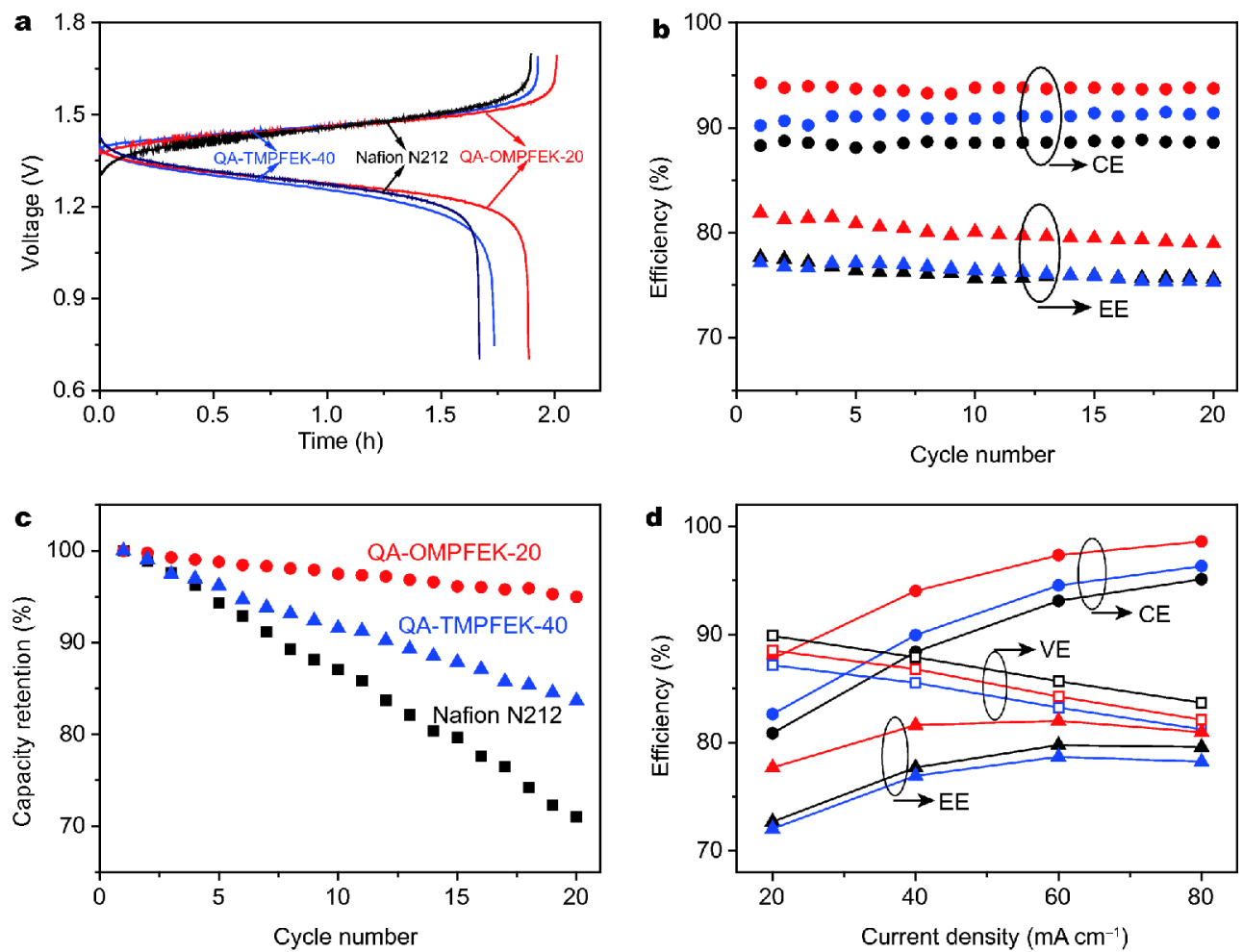

Figure 8 Cell performance of the QA-OMPFEK-20 (red), QA-TMPFEK-40 (blue), and Nafion N212 (black) batteries: (a) initial charge/discharge curves, (b) efficiencies, and (c) discharge capacity retention during galvonostatic cycling at a current density $40 \mathrm{~mA} \mathrm{~cm}^{-2}$; (d) rate performance of the VRFBs.

(fluorenyl ether ketone)s (QA-OMPFEKs) with different IECs were then obtained from this newly designed compound $\mathbf{b}$ for high performance AEMs. The experimental results revealed that the QA-OMPFEK-20 with an IEC of $1.66 \mathrm{mmol} \mathrm{g}^{-1}$ exhibited a $\mathrm{SO}_{4}^{2-}$ conductivity of $9.62 \mathrm{mS} \mathrm{cm}^{-1}$ at room temperature, which was much higher than that of a control AEM (QA-TMPFEK-40, IEC $=1.73 \mathrm{mmol} \mathrm{g}^{-1}$ ) made from the DMHPF using a same protocol. This enhanced $\mathrm{SO}_{4}^{2-}$ conductivity of QA-OMPFEK-20 was attributed to the densely functionalized QA groups that formed well-defined ion-segregated phase, which was validated successfully by the SAXS technique. Along with the water uptake, swelling ratio, thermal stability, chemical stability and mechanical property characterizations, it was demonstrated that the QA-OMPFEK-20 could be a promising candidate for high performance AEMs under acidic conditions. Indeed, the VRFB assembled with QA-OMPFEK-20 exhibited higher Coulombic and energy efficiencies than the VRFBs assembled with QA-TMPFEK-40 and Nafion N212 under the same condition. Therefore, the Ullmann coupling is a powerful tool for the synthesis of multi-benzylmethylcontaining bisphenol monomers for ion-segregated
AEMs based on poly(arylene ether) backbones.

Received 15 March 2018; accepted 12 May 2018;

published online 8 June 2018

1 Choi C, Kim S, Kim R, et al. A review of vanadium electrolytes for vanadium redox flow batteries. Renew Sustain Energy Rev, 2017, 69: $263-274$

2 Schwenzer B, Zhang J, Kim S, et al. Membrane development for vanadium redox flow batteries. ChemSusChem, 2011, 4: 13881406

3 Chen D, Hickner MA, Agar E, et al. Selective anion exchange membranes for high coulombic efficiency vanadium redox flow batteries. Electrochem Commun, 2013, 26: 37-40

4 Zhang S, Yin C, Xing D, et al. Preparation of chloromethylated/ quaternized poly(phthalazinone ether ketone) anion exchange membrane materials for vanadium redox flow battery applications. J Membrane Sci, 2010, 363: 243-249

5 Xi J, Jiang B, Yu L, et al. Membrane evaluation for vanadium flow batteries in a temperature range of $-20-50^{\circ} \mathrm{C}$. J Membrane Sci, 2017, 522: 45-55

$6 \mathrm{Wu} \mathrm{C}, \mathrm{Lu} \mathrm{S}$, Wang $\mathrm{H}$, et al. A novel polysulfone-polyvinylpyrrolidone membrane with superior proton-to-vanadium ion selectivity for vanadium redox flow batteries. J Mater Chem A, 2016, 4: 1174-1179

7 Amel A, Smedley SB, Dekel DR, et al. Characterization and chemical stability of anion exchange membranes cross-linked with 
polar electron-donating linkers. J Electrochem Soc, 2015, 162: F1047-F1055

8 Teng X, Dai J, Su J, et al. A high performance polytetrafluoroethene/Nafion composite membrane for vanadium redox flow battery application. J Power Sources, 2013, 240: 131-139

9 Chen D, Kim S, Li L, et al. Stable fluorinated sulfonated poly (arylene ether) membranes for vanadium redox flow batteries. RSC Adv, 2012, 2: 8087-8094

10 Zeng L, Zhao TS, Wei L, et al. Highly stable pyridinium-functionalized cross-linked anion exchange membranes for all vanadium redox flow batteries. J Power Sources, 2016, 331: 452-461

11 Sata T. Studies on anion exchange membranes having permselectivity for specific anions in electrodialysis-effect of hydrophilicity of anion exchange membranes on permselectivity of anions. J Membrane Sci, 2000, 167: 1-31

12 Hickner MA, Herring AM, Coughlin EB. Anion exchange membranes: Current status and moving forward. J Polym Sci Part BPolym Phys, 2013, 51: 1727-1735

13 Ran J, Wu L, Ru Y, et al. Anion exchange membranes (AEMs) based on poly(2,6-dimethyl-1,4-phenylene oxide) (PPO) and its derivatives. Polym Chem, 2015, 6: 5809-5826

14 Kumar M, Tripathi BP, Saxena A, et al. Electrochemical membrane reactor: Synthesis of quaternary ammonium hydroxide from its halide by in situ ion substitution. Electrochim Acta, 2009, 54: 1630-1637

15 Cheng J, He G, Zhang F. A mini-review on anion exchange membranes for fuel cell applications: Stability issue and addressing strategies. Int J Hydrogen Energy, 2015, 40: 7348-7360

16 Li N, Zhang Q, Wang C, et al. Phenyltrimethylammonium functionalized polysulfone anion exchange membranes. Macromolecules, 2012, 45: 2411-2419

17 Yang Y, Knauss DM. Poly(2,6-dimethyl-1,4-phenylene oxide)- $b$ poly(vinylbenzyltrimethylammonium) diblock copolymers for highly conductive anion exchange membranes. Macromolecules, 2015, 48: 4471-4480

18 Zhu L, Pan J, Christensen CM, et al. Functionalization of poly(2,6dimethyl-1,4-phenylene oxide)s with hindered fluorene side chains for anion exchange membranes. Macromolecules, 2016, 49: 33003309

19 He Y, Pan J, Wu L, et al. A novel methodology to synthesize highly conductive anion exchange membranes. Sci Rep, 2015, 5: 13417

20 He S, Liu L, Wang X, et al. Azide-assisted self-crosslinking of highly ion conductive anion exchange membranes. J Membrane Sci, 2016, 509: 48-56

21 Chen D, Hickner MA. Degradation of imidazolium- and quaternary ammonium-functionalized poly(fluorenyl ether ketone sulfone) anion exchange membranes. ACS Appl Mater Interfaces, 2012, 4: 5775-5781

22 Tanaka M, Fukasawa K, Nishino E, et al. Anion conductive block poly(arylene ether)s: synthesis, properties, and application in alkaline fuel cells. J Am Chem Soc, 2011, 133: 10646-10654

23 Shimada M, Shimada S, Miyake J, et al. Anion conductive aromatic polymers containing fluorenyl groups: Effect of the position and number of ammonium groups. J Polym Sci Part A-Polym Chem, 2016, 54: 935-944

24 Lai AN, Wang LS, Lin CX, et al. Phenolphthalein-based poly(arylene ether sulfone nitrile)s multiblock copolymers as anion exchange membranes for alkaline fuel cells. ACS Appl Mater Interfaces, 2015, 7: 8284-8292

25 Li X, Nie G, Tao J, et al. Assessing the influence of side-chain and main-chain aromatic benzyltrimethyl ammonium on anion exchange membranes. ACS Appl Mater Interfaces, 2014, 6: 75857595

26 Zhang Z, Shen K, Lin L, et al. Anion exchange membranes based on tetra-quaternized poly(arylene ether ketone). J Membrane Sci, 2016, 497: 318-327

27 Tanaka M, Koike M, Miyatake K, et al. Synthesis and properties of anion conductive ionomers containing fluorenyl groups for alkaline fuel cell applications. Polym Chem, 2011, 2: 99-106

28 Hibbs MR. Alkaline stability of poly(phenylene)-based anion exchange membranes with various cations. J Polym Sci Part B-Polym Phys, 2013, 51: 1736-1742

29 Wang C, Shen B, Xu C, et al. Side-chain-type poly(arylene ether sulfone)s containing multiple quaternary ammonium groups as anion exchange membranes. J Membrane Sci, 2015, 492: 281-288

30 Varcoe JR, Atanassov P, Dekel DR, et al. Anion-exchange membranes in electrochemical energy systems. Energy Environ Sci, 2014, 7: 3135-3191

31 Weiber EA, Jannasch P. Ion distribution in quaternary-ammonium-functionalized aromatic polymers: effects on the ionic clustering and conductivity of anion-exchange membranes. ChemSusChem, 2014, 7: 2621-2630

32 Chen D, Hickner MA. Ion clustering in quaternary ammonium functionalized benzylmethyl containing poly(arylene ether ketone)s. Macromolecules, 2013, 46: 9270-9278

33 Chen D, Wang S, Xiao M, et al. Synthesis and properties of novel sulfonated poly(arylene ether sulfone) ionomers for vanadium redox flow battery. Energy Convers Manage, 2010, 51: 2816-2824

34 Fujimoto $\mathrm{CH}$, Hickner MA, Cornelius CJ, et al. Ionomeric poly (phenylene) prepared by Diels-Alder polymerization: synthesis and physical properties of a novel polyelectrolyte. Macromolecules, 2005, 38: 5010-5016

35 Largier TD, Cornelius CJ. Random quaternary ammonium DielsAlder poly(phenylene) copolymers for improved vanadium redox flow batteries. J Power Sources, 2017, 352: 149-155

36 Wiedemann E, Heintz A, Lichtenthaler RN. Transport properties of vanadium ions in cation exchange membranes: Determination of diffusion coefficients using a dialysis cell. J Membrane Sci, 1998, 141: $215-221$

37 Kim S, Tighe TB, Schwenzer B, et al. Chemical and mechanical degradation of sulfonated poly(sulfone) membranes in vanadium redox flow batteries. J Appl Electrochem, 2011, 41: 1201-1213

38 Xing D, Zhang S, Yin C, et al. Effect of amination agent on the properties of quaternized poly(phthalazinone ether sulfone) anion exchange membrane for vanadium redox flow battery application. J Membrane Sci, 2010, 354: 68-73

39 Cheng S, Beyer FL, Mather BD, et al. Phosphonium-containing ABA triblock copolymers: controlled free radical polymerization of phosphonium ionic liquids. Macromolecules, 2011, 44: 6509-6517

40 Yan J, Hickner MA. Anion exchange membranes by bromination of benzylmethyl-containing poly(sulfone)s. Macromolecules, 2010, 43: 2349-2356

41 Lin X, Varcoe JR, Poynton SD, et al. Alkaline polymer electrolytes containing pendant dimethylimidazolium groups for alkaline membrane fuel cells. J Mater Chem A, 2013, 1: 7262-7269

42 Weiber EA, Jannasch P. Polysulfones with highly localized imidazolium groups for anion exchange membranes. J Membrane Sci, 2015, 481: 164-171

43 Yun S, Parrondo J, Ramani V. Derivatized cardo-polyetherketone anion exchange membranes for all-vanadium redox flow batteries. 
J Mater Chem A, 2014, 2: 6605-6615

44 Kornyshev AA, Kuznetsov AM, Spohr E, et al. Kinetics of proton transport in water. J Phys Chem B, 2003, 107: 3351-3366

45 Matsumoto K, Higashihara T, Ueda M. Locally and densely sulfonated poly(ether sulfone)s as proton exchange membrane. Macromolecules, 2009, 42: 1161-1166

46 Li X, Liu Q, Yu Y, et al. Quaternized poly(arylene ether) ionomers containing triphenyl methane groups for alkaline anion exchange membranes. J Mater Chem A, 2013, 1: 4324-4335

47 Ono H, Miyake J, Shimada S, et al. Anion exchange membranes composed of perfluoroalkylene chains and ammonium-functionalized oligophenylenes. J Mater Chem A, 2015, 3: 21779-21788

48 Zhang S, Zhang B, Xing D, et al. Poly(phthalazinone ether ketone ketone) anion exchange membranes with pyridinium as ion exchange groups for vanadium redox flow battery applications. J Mater Chem A, 2013, 1: 12246-12254
49

Jiang B, Wu L, Yu L, et al. A comparative study of Nafion series membranes for vanadium redox flow batteries. J Membrane Sci, 2016, 510: $18-26$

Acknowledgements This work was supported by the National Natural Science Foundation of China (51503038).

Author contributions Chen D designed the experiments; Chen Y performed the experiments; Chen $\mathrm{Y}$ and Chen D analyzed the data and wrote the paper; all authors discussed the results and commented on the manuscript.

Conflict of interest The authors declare no conflict of interest.

Supplementary information Supporting data are available in the online version of the paper.

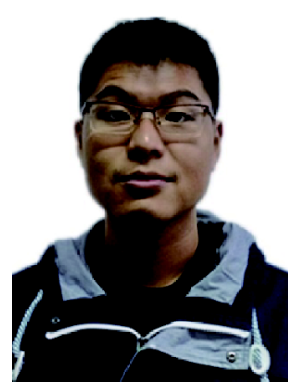

Yu Chen is currently a PhD student under the supervision of Prof. Dongyang Chen at the College of Materials Science and Engineering, Fuzhou University. His current research focuses on the synthesis of ion-containing polymers for battery separators.

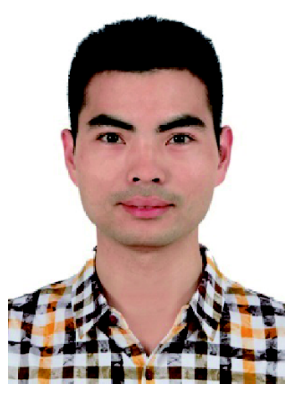

Dongyang Chen is a professor at the College of Materials Science and Engineering, Fuzhou University. He obtained his PhD from Sun Yat-sen University in 2011. After that, he went to the Pennsylvania State University (USA, 2011-2013) and Northwestern University (USA, 2013-2015) as a postdoctoral fellow. His research involves the development of high performance polymeric materials for flow batteries, lithium batteries, and fuel cells.

\section{基于乌尔曼偶联反应制备的密集季铵化型全钒液流电池阴离子交换膜}

陈显 ${ }^{1}$, 林起浪 $^{1}$, 郑玉婴 ${ }^{1}$, 于岩 ${ }^{1,2}$, 陈栋阳 ${ }^{1,2^{*}}$

摘要 离子传导率和选择性是全钒液流电池隔膜的两项核心性能指标. 本文基于乌尔曼偶联反应设计合成含八苯甲基的双酚单体，然后 依次将其聚合、澳甲基化、季铵化制得一系列密集季铵化型阴离子交换膜(QA-OMPFEKs). 产物QA-OMPFEK-20（离子交换容量 IEC $=1.66 \mathrm{mmol} \mathrm{g}^{-1}$ ) 的室温 $\mathrm{SO}_{4}{ }^{2-}$ 传导率为 $9.62 \mathrm{mS} \mathrm{cm}^{-1}$, 明显高于参照样品QA-TMPFEK-40 (IEC $=1.73 \mathrm{mmol} \mathrm{g}^{-1}$ ) 的 $4.82 \mathrm{mS} \mathrm{cm}{ }^{-1}$. 这归因 于QA-OMPFEK-20经小角X射线散射所证实的离子聚集型结构. 此外, QA-OMPFEK-20的钒离子渗透率 $\left(1.24 \times 10^{-14} \mathrm{~m}^{2} \mathrm{~s}^{-1}\right)$ 明显低于QATMPFEK-40 $\left(5.40 \times 10^{-13} \mathrm{~m}^{2} \mathrm{~s}^{-1}\right)$ 和Nafion N212 $\left(5.36 \times 10^{-12} \mathrm{~m}^{2} \mathrm{~s}^{-1}\right)$, 从而使其全钒液流电池的库伦效率和能量效率最高. 可见, 乌尔曼偶联 反应是合成高性能全钒液流电池阴离子交换膜的有效路径. 